\title{
Acceptance of Santo Giorno cheese typical of the Southwestern region of Paraná, Brazil
}

\author{
Edimir Andrade Pereira ${ }^{1}$ Roberta Roncatti ${ }^{1}$ Carla Todescatto ${ }^{1}$ Simone Beux $^{1}$ \\ João Francisco Marchi $^{2}$ Marina Leite Mitterer Daltoé ${ }^{*}$
}

\author{
${ }^{1}$ Universidade Tecnológica Federal do Paraná (UTFPR), 85503-390, Campus Pato Branco, Pato Branco, PR, Brasil. E-mail: marinadaltoe@utfpr.edu.br \\ *Corresponding author. \\ ${ }^{2}$ Universidade Tecnológica Federal do Paraná (UTFPR), Campus Francisco Beltrão, Francisco Beltrão, PR, Brasil.
}

\begin{abstract}
Santo Giorno cheese, obtained from raw milk and selected autochthonous starters, is emerging as the newest typical food product from the Southwestern region of Paraná, Brazil. The objective of this study was to evaluate the acceptance of the cheese with two ripening times of 60 and 180 days, produced in two dairy factories, testing two starters and two preservatives. Subjective sensory evaluation was applied using 129 consumers and hedonic scales for the attributes and for purchasing intent. A questionnaire involving the rate of cheese consumption was also used. The results suggested good reproducibility of the cheese preparation by the dairy factories, with no significant differences between the type of preservative used and the suitability of the two types of starter tested. An inverse relationship between hedonic scores for attributes (appearance, color, odor, texture, flavor) and ripening time was observed, except for texture. By applying multinomial logistic regression and a box plot analysis, a significant effect of age on cheese purchasing intent was verified, with a mean acceptance rate of $87.8 \%$ for 60 days ageing and $81.8 \%$ for 180 days ageing. Results revealed a possible Santo Giorno cheese public of older consumers who had a cheese consuming habit.

Key words: consumer, hedonic scale, purchasing intent, starters, raw milk.
\end{abstract}

Aceitação do queijo Santo Giorno típico da região Sudoeste do Paraná

RESUMO: Obtido a partir de leite cru e fermento autóctone selecionado, o queijo Santo Giorno surge como o mais novo produto alimentício típico da Região Sudoeste do Paraná. O objetivo do presente trabalho foi avaliar a aceitação do queijo em dois tempos de maturação 60 e 180 dias produzidos em dois laticinios, onde foram testados dois fermentos desenvolvidos e dois conservantes. Avaliação sensorial subjetiva foi aplicada a um total de 129 consumidores através do uso de escalas hedônicas por atributos e intenção de compra. Questionário envolvendo a frequência de consumo de queijos também foi utilizado. Os resultados sugeriram reprodutibilidade na elaboração dos queijos pelos laticínios, diferenças não significativas no tipo de conservante a ser empregado e aptidão para os dois tipos de fermentos testados. Relação inversa entre os escores hedônicos dos atributos (aparência, cor, odor, sabor) e o tempo de maturação foram verificadas, exceção para o atributo textura. Mediante aplicação de regressão logística multinomial e análises por box plot verificou-se importante efeito da idade na intenção de compra do queijo. Com índice de aceitação médio de 87,8\% para 60 dias e 81,8\% para 180 dias, os resultados revelam um possível público do queijo Santo Giorno, consumidores com mais idade e que possuem o hábito de consumir queijos.

Palavras-chave: consumidor, escala hedônica, intenção de compra, fermentos, leite cru.

\section{INTRODUCTION}

In general, cheese quality is mostly dependent on the LAB (Lactic acid bacteria) fermentations, which influence its sensory and aromatic features (STEELE et al., 2013). Addition of autochthonous cultures to make cheese of a more constant quality, while preserving the sensory peculiarities of the cheeses made in each area, deserves to be investigated (BOZOUDI \& TORRIANI, 2016).
Santo Giorno cheese results from partnerships between the Belluno Province, the Italian Associazione Bellunesi nel Mondo (Veneto - Italy), the Agência de Desenvolvimento Regional do Sudoeste do Paraná (UTFPR), Pato Branco, Francisco Beltrão and the Dois Vizinhos campus, Department of Agronomy, Natural Food Resources, Animals and the Environment of Padua University, and Bioagro Societá Partecipata de Veneto Agricoltura, amongst others. The product is 
classified in the fine cheese category and carries a regional identity.

Cheese is the curd formed when milk is coagulated by adding enzymes or by the lactic acid produced by the activity of naturally present or intentionally added microorganisms. After syneresis, the cheese undergoes ripening for a certain period of time (ORDÓÑEZ et al., 2005). It is during this ripening stage that the lactic acid bacteria play a key role in lipid and protein hydrolysis, providing the characteristic sensory attributes (SBAMPATO et al., 2000). According to the US Food and Drug Administration a 60-day ripening period is necessary to improve the microbiological quality of raw milk cheeses (D’AMICO et al., 2010).

Cheeses made from raw milk are characterized by having more intense and varied flavors when compared with those obtained from pasteurized milk, due to the presence of the endogenous milk microbiota (DELGADO et al., 2011). The present research represents the first contribution to knowledge of the sensory analysis of Santo Giorno cheese produced with the addition of autochthonous cultures. The objective of the present study was to evaluate the acceptance of Santo Giorno cheese prepared from raw milk, with two ripening times of 60 and 180 days, produced in two dairy factories, where two starters and two preservatives were tested.

\section{MATERIALS AND METHODS}

\section{Raw materials}

Raw cow's milk. Two endogenous lactic starters were used, A and B (combination of different strains), containing Streptococcus thermophilus and Lactobacillus delbruckeii sb. bulgaricus bacteria, isolated from milk obtained in the Southwest of Paraná, Brazil. Sodium nitrate and lysozyme (preservatives - to inhibit late blowing). Chymosin rennet (bovine rennet).

\section{Cheese elaboration}

The cheeses were produced in two dairy factories: dairy 1, located in the city of Coronel Vivida - PR, and dairy 2, located in the city of Renascença - PR.

For each cheese formulation, 2000 liters of raw, cold, homogenized whole milk were used. The starter (A or B) was immediately added (1 sachet $(50 \mathrm{~g})$ for every 2000 liters of milk) and sodium nitrate $\left(400 \mathrm{~g} 2000\right.$ liters $^{-1}$ of milk) or lysozyme (40g 2000 liters $^{-1}$ of milk) and stirred constantly for 10 minutes. Chymosin (powdered form, strength of
$1: 100,000)$ was then added $\left(80 \mathrm{~g} 2000\right.$ liters $\left.^{-1}\right)$ and the milk allowed to coagulate for 25 to 30 minutes at 35 $36^{\circ} \mathrm{C}$. After sufficient coagulation time, the curd was cut (size of a corn grain), and stirred for 10 minutes. The cut curd was indirectly heated to $44^{\circ} \mathrm{C}$ and stirred for 15-30 minutes, followed by mass draining.

The drained curd was molded containers $(10 \times 25 \mathrm{~cm})$ and microholes to allow for elimination of whey. The final weight was approximately $5 \mathrm{~kg}$. Cheeses were pressed twice for 15 minutes ( 3 bar), and then turned every half hour until the $\mathrm{pH}$ reached 5.20 , and then placed in a refrigerator for 12 hours. The cheeses were subsequently brined for 2 days ( $\mathrm{pH} 5.25$ and $17-18 \%$ salt solution), and then dried for 25 days in humidity controlled $(85-87 \% \mathrm{RH})$, associated with a ventilation system and cooling (6$8^{\circ} \mathrm{C}$ ), turning the cheeses every 2 days. After 25 days the cheeses were coated with an overlay of polyvinyl acetate polymer and allowed to ripen for 60 or 180 days in chambers at between 12 and $14^{\circ} \mathrm{C}$, turning at least once a week.

The cheeses produced were identified with abbreviations according to the starter and preservative used and the dairy where they were produced: CAN 1 (Starter A, Sodium Nitrate, Dairy 1); CAN 2 (Starter A, Sodium Nitrate, Dairy 2); CBL 1 (Starter B, Lysozyme, Dairy 1); and CBL 2 (Starter B, Lysozyme, Dairy 2).

\section{Application of hedonic tests to assess the different formulations}

The target consumers were 129 Brazilian students, faculty and staff from the UTFPR Pato Branco campus, aged between 20 and 60, of which seventy-two were female and fifty-seven male. A five-point hedonic scale was used to evaluate the attributes for consumer acceptance, varying from disliked extremely (1) to liked extremely (5). The sensory attributes evaluated were color, appearance, odor, texture and taste. A 3-point structured scale was applied to evaluate purchasing intent, ranging from would not buy (1), may buy/may not buy (2) to would buy (3). The consumers also filled in a questionnaire about their frequency of cheese consumption with the following points: no consumption (1); once a month (2); more than once per month (3); once weekly (4) and every day (5).

Tests were applied to cheeses with ripening times of 60 and 180 days. The cheeses were cut into cubes $(2.0 \times 2.0 \times 2.0 \mathrm{~cm})$ and offered in a monadic way on a plastic dish coded with three random digits. Water and plain crackers were provided to clean the palate between samples. The tests were carried out 
in individual sensory analysis booths at the Food Technology Laboratory- UTFPR.

\section{Statistical analysis}

The mean hedonic scores for each attribute were evaluated by the Tukey means test, and a multivariate ANOVA with two factors (cheese and ripening time) applied to check whether the effects of the two independent variables were significant for both acceptance and purchasing intent. Acceptance and purchasing intent rates were calculated from the averages obtained, taking the maximum value of the scale (5) as 100\% (MITTERER-DALTOÉ et al., 2013a). The $Z$ test was employed to assess differences between the ripening times for sensory attributes and purchasing intent. A multinomial logistic regression was used to evaluate the effects of age, gender and cheese consumption frequency on purchasing intent and hedonic score for flavor, just for the 60 days ripening time. A box plot was applied to the median values to better understand the effects of the variables of age, gender and cheese consumption frequency on purchasing intent. Results were analyzed using the Statistica Program 12.7.

\section{RESULTS AND DISCUSSION}

Figure 1 shows the results obtained for purchasing intent and the scores attributed in the hedonic acceptance test for each attribute evaluated for the different formulations at two ripening times. There was no significant difference between the formulations and ripening times. Equality in the hedonic scores for the samples was considered to be favorable, since they differed according to production place, type of preservative and yeast employed.

No difference in sensory acceptance by the consumers suggested the possibility of reproducibility of cheese preparation by different dairy industries in the region, independent of the type of preservative used and the egalitarian biochemical activities of two yeasts. This last aspect is very positive, since both starters not only showed strong bacterial activity with respect to fermentation (ATTORNI et al., 2014), but also with regard to the ripening process, a step which is largely responsible for the sensory attributes (DIEZHANDINO \& FERNÁNDEZ, 2016). Thus, both starters were able to produce Santo Giorno cheese. To produce cheese in a factory, the option of two starters for the elaboration of the same cheese is of fundamental importance, considering the possibility of some problem occurring due to starter inactivation by bacteriophages (ATTORNI et al., 2014).
Although the means test suggested equality between the samples with respect to acceptance, the behavior of the curves was similar for all the hedonic results and for purchasing intent. There was an inverse relationship between the scores and ripening time, behavior best observed by application of the multivariate ANOVA test (Table 1).

The values for significance indicated a significant effect $(\mathrm{P} \leq 0.05)$ of ripening time on purchasing intent and on the sensory attributes, except for the attribute of texture. Although it is known that the texture of cheeses changes during the ripening time, (HORT et al., 1996), in hedonic terms there was no influence on the consumers.

If one evaluates the results shown in figure 1 and table 1 in parallel, a significant decrease was reported in the hedonic scores for appearance, color, odor and flavor as from 60 days of ripening time, as shown by the scores obtained after 180 days. This decrease was possibly related to the occurrence of proteolysis and lipolysis during ripening. Proteolysis and lipolysis are the most important reactions occurring during cheese ripening, being responsible for the texture, flavor and aroma (DIEZHANDINO \& FERNÁNDEZ, 2016). Numerous substances accumulate during ripening; and therefore, the cheese composition and consequently its sensory attributes suffer considerable changes during the ripening process (DELGADO et al., 2011; DIEZHANDINO \& FERNÁNDEZ, 2016). More mature cheeses have more intense sensory characteristics, qualities which were apparent in the research of DIEZHANDINO \& FERNÁNDEZ (2016). The authors reported that the cheese samples evaluated after a longer ripening time (120 days) were associated with attributes such as pungency and salty flavors and pungent and sour odors, attributes characteristic of the hydrolytic processes occurring during maturation.

One cannot claim this to be the motive for the inverse relationship between ripening time and hedonic scores, since the hedonic scales used in the evaluation of acceptance do not provide information on the consumers' reasons for liking or disliking the product (LIM, 2011). However, as a possible cause it has been suggested that fresh or conventional cheeses such as mozzarella and prato (CARVALHO et al., 2015), cheeses, with softer sensory characteristics, are more a part of Brazilian culture then fine matured cheeses.

Since the different cheese formulations showed no significant differences between their means in the difference test (Figure 1 and Table 1) and the ripening time did have a significant effect 

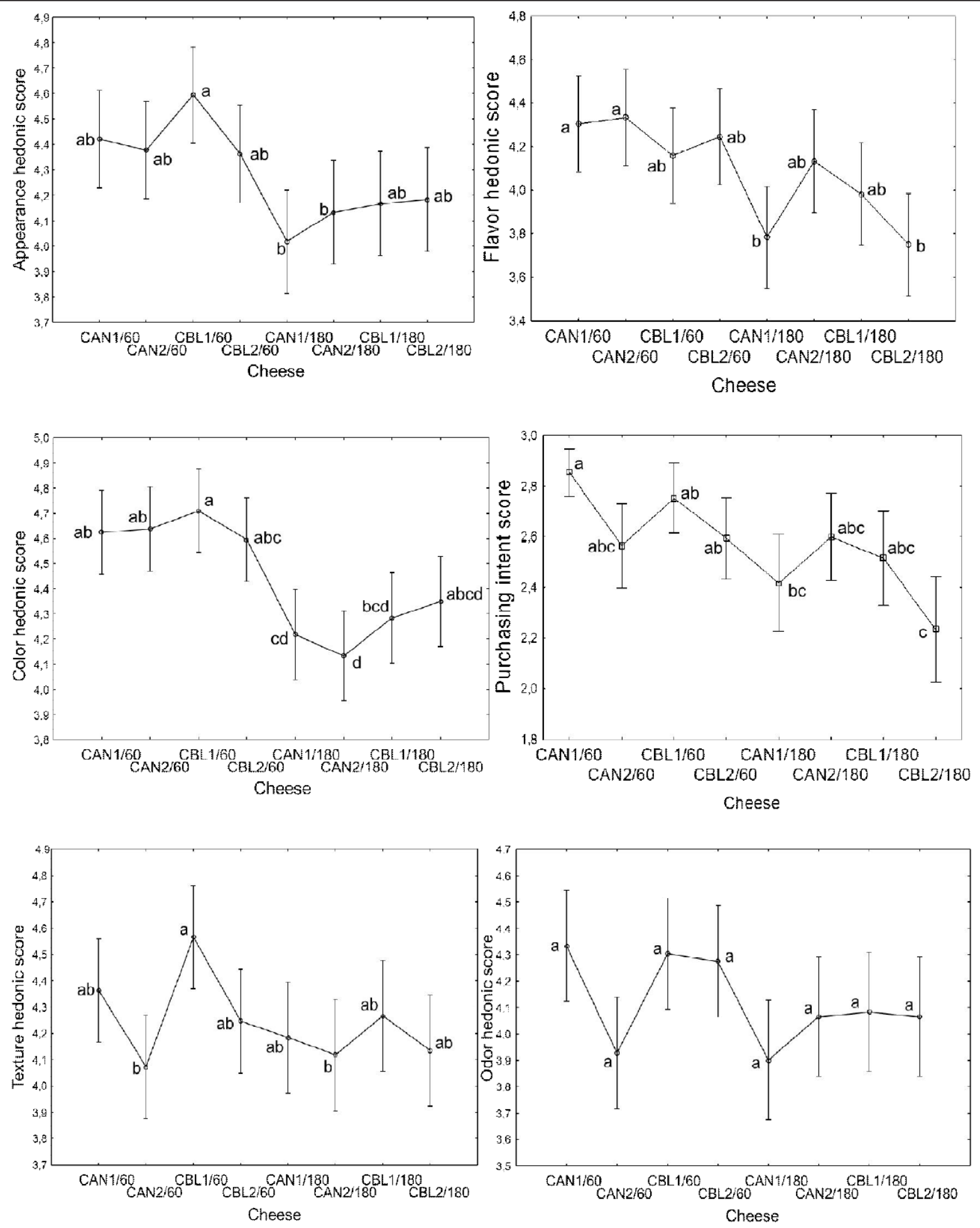

Figure 1 - Hedonic evaluation and purchasing intent for the different samples and ripening times - Different letters show significant differences $(\mathrm{P} \leq 0.05)$. 
Table 1 - Multivariate ANOVA - significance (P value) for the hedonic scores and purchasing intent.

\begin{tabular}{|c|c|c|c|c|c|c|}
\hline Effect & Appearance & Color & Odor & Texture & Flavor & Purchasing Intent \\
\hline Cheese & 0.4137 & 0.5844 & 0.2929 & 0.0168 & 0.1979 & 0.0234 \\
\hline Ripening time & $<0.001$ & $<0.001$ & 0.0218 & 0.0636 & $<0.001$ & $<0.001$ \\
\hline Cheese X Ripening time & 0.5375 & 0.5128 & 0.0797 & 0.4183 & 0.2788 & 0.0261 \\
\hline
\end{tabular}

Cheeses: CAN1, CAN2, CBL1, CBL2. Ripening times: 60 days, 180 days.

on the scores (Table 1), the acceptance rates and purchasing intent were calculated considering the scores for all the cheese formulations with the two different ripening times. From the results after $\mathrm{z}$ test between ripening times, one can see the differences $(\mathrm{P} \leq 0.05)$ in the sensory attributes and purchasing intent between the times of 60 and 180 days. Results corroborated the lack of a significant effect of time on the acceptance value for the attribute of texture.

Higher acceptance rates can be seen for the sensory attributes of color $(93 \%$ in $60 \mathrm{~d} ; 85 \%$ in $180 \mathrm{~d} ; \mathrm{P}<0.01)$ and appearance $(89 \%$ in $60 \mathrm{~d} ; 82 \%$ in 180d; $\mathrm{P}<0.01)$, followed by texture $(86 \%$ in $60 \mathrm{~d}$; $83 \%$ in $180 \mathrm{~d}$; $\mathrm{P}=0.06)$, odor $(84 \%$ in $60 \mathrm{~d} ; 82 \%$ in $180 \mathrm{~d} ; \mathrm{P}=0.02)$ and taste $(85 \%$ in $60 \mathrm{~d} ; 78 \%$ in $180 \mathrm{~d}$; $\mathrm{P}<0.01$ ), these being the attributes with the lowest acceptance rates, reinforcing the idea of the difficulty of Brazilians in consuming mature cheeses, which have intense flavors and odors, possibly reflecting the lack of consumption habits.

Purchasing intent $(90 \%$ in $60 \mathrm{~d} ; 81 \%$ in180d; $\mathrm{P}<0.01)$ showed the highest rates after 60 days of ripening time, this being a very positive result that strengthens the acceptance of Santo Giorno cheese. According to (QUEIROZ \& TREPTOW, 2006), acceptance is the experience characterized by a positive attitude, representing the fact that an individual or a population is favorable to the consumption of a determined product.
In order to better explore the acceptance of Santo Giorno cheese, a multinomial logistic regression was applied (Table 2) with the intention of assessing the effects of age, gender and cheese consumption frequency on purchasing intent and the hedonic score for flavor. Consumers considered the attribute of flavor very important in the assessment of cheese (DELGADO et al., 2011). In parallel, a behavioral analysis was made of the effect of these variables on purchasing intent using a box plot (Figure 2). Gender and cheese consumption frequency showed no significant effect either on purchasing intent or on the hedonic evaluation of the attribute of flavor. However, age, although not significant at $\alpha=5 \%$, showed significance at 0.05 for both dependent variables, highlighting $\mathrm{P}=0.09$ for purchasing intent.

The behavior of purchasing intent with respect to age groups can be better visualized by the box plot analyses. Graphs indicated a predominance of the maximum score (3) for all age groups, considering the median values. Group 1 (18-25 years); although, showing a median score of 3 , presented a lower density in their results, with an interquartile range varying from 2 to 3 and minimum recorded score of 1 . This behavior was not registered in the older groups.

While both gender groups featured medians with a score of 3 and showed no change in the interquartile range, there was variation in the cheese consumption frequency between the groups.

Table 2 - Statistical significance (P value) with respect to age, gender and cheese consumption frequency for purchasing intent and the hedonic score for flavor by logistic regression.

\begin{tabular}{lcccc}
\hline Effect & - & & \\
& & & \\
& & & \\
& Wald & P value & Wald & P value \\
Age & 4.8141 & 0.0900 & 10.142 & 0.1188 \\
Gender & 0.9461 & 0.6321 & 2.9886 & 0.3934 \\
Cheese consumption frequency & 0.6473 & 0.7236 & 2.2951 & 0.5134 \\
\hline
\end{tabular}

Age: 20 to 60 years. Gender: Female, male. Cheese consumption frequency: no consumption (1); once a month (2); more than once a month (3); once weekly (4) and every day (5). 

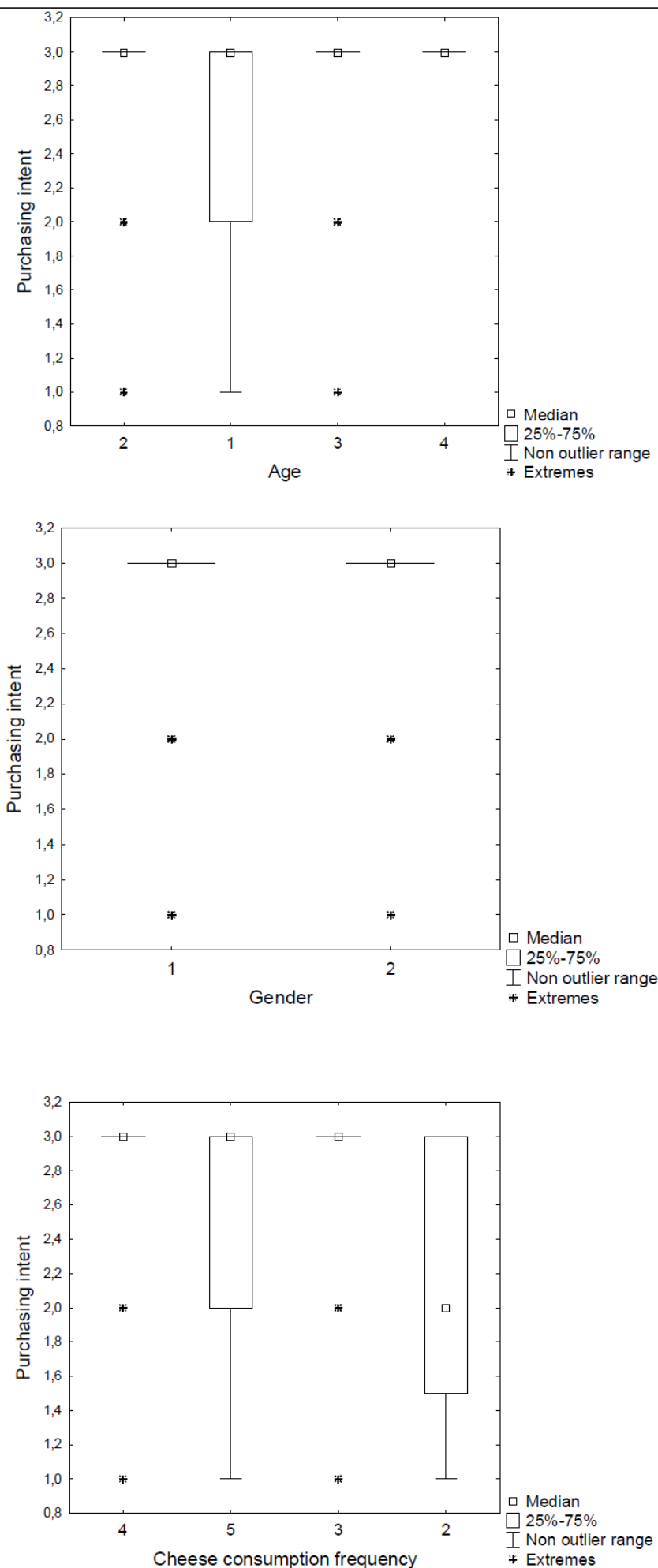

Figure 2 - Box plot of the purchasing intent for Santo Giorno cheese with respect to age, gender and cheese consumption frequency. Purchasing intent: 1 (not buy); 2 (maybe buy, maybe not buy), 3 (buy). Age Bands: 1 (18-25 years); 2 (25-35 years); 3 (36-50 years); 4 (50-65). Gender: 1 (Female); 2 (Male). Cheese consumption frequency: 1 (non-consumption), 2 (once a month consumption), 3 (more than once a month consumption), 4 (once a week consumption), 5 (daily consumption). Median: $\square ; 25 \%-75 \%$ of observations; non outlier range; extremes: *. 
Group 2, represented by consumers with a lower cheese consumption index (once a month), was reported to show a lower median (2), highlighting purchasing doubts. The other consumer groups registered medians with the maximum score. Group 5 presented a variation in the interquartile range.

The fact that the group with low cheese consumption showed greater doubts with respect to buying the Santo Giorno cheese corroborates what the literature relates concerning behavior (consumption frequency) and behavior intent (buying to consume). The Planned Behavior Theory (AJZEN, 1991) has been applied to explain the intent and consumption of different types of foods such as organic foods (ARVOLA et al., 2008), ready to eat foods (OLSEN et al., 2010), genetically modified foods (PRATI et al., 2012) and fish (MITTERERDALTOÉ et al., 2013b). It was derived from the Reasoned Action Theory (AJZEN \& FISHBEIN, 1980) in which the authors stated that individual behavior is a result of behavior intention. For these authors, intent is the best behavior predictor and can be understood as cognitive representation of an individual who is ready to "perform the behavior."

Therefore, consumers who said they only consumed cheese once a month, in fact submitted the lower purchasing intent/cheese consumption. This behavior and the influence of age lead to the suggestion that the target consumers for Santo Giorno cheese should be older consumers who already have the habit of consuming different cheese varieties.

\section{CONCLUSION}

Santo Giorno cheese proved to be a potentially acceptable food by older consumers with cheese consumption habits. In addition to checking if Santo Giorno cheese had a potential market, the hedonic tests suggested that the two starters under study were suitable for the elaboration of a single cheese with unique sensory characteristics. Although the consumer results provided important answers, future research should include sensory evaluations using the quantitative descriptive analysis (QDA) and trained panelists. Thus the difference between the ripening times shown in the consumer acceptance test could be confirmed, or otherwise.

\section{ACKNOWLEDGEMENTS}

The authors are grateful to The Bellunesi in the World Association; The Region of Veneto and Province of Belluno
- IT; The Mezzomo Family; The Paraná Southwest Regional Development Agency; The HE and Primo Queijo Dairies; and the Universidade Tecnológica Federal do Paraná (UTFPR).

\section{REFERENCES}

AJZEN, I. The theory of planned behavior. Organizational Behavior and Human Decision Process, v.50, p.179-211, 1991.

AJZEN, I.; FISHBEIN, M. Understanding attitudes and prediscting social behavior. Englewood Cliffs: Prentice-Hall, 1980. 278p.

ARVOLA, A. et al. Predicting intentions to purchase organic food: the role of affective and moral attitudes in the Theory of Planned Behavior. Appetite, v.50, p.443-454, 2008.

ATTORNI, B. et al. Santo Giorno. Um queijo de alta qualidade. Francisco Beltrão: Jornal de Beltrão, 2014. 98p.

BOZOUDI, D.; TORRIANI, S. Assessment of microbial diversity of the dominant microbiota in fresh and mature PDO Feta cheese made at three mountainous areas of Greece. LWT-Food Science and Technology, v.72, p.525-533, 2016.

D'AMICO, D.J. et al. Behavior of Escherichia coli O157: H7 during the Manufacture and aging of gouda and stirred-curd cheddar cheeses manufactured from raw milk. Journal of Food Protection, v.73, n.12, p.2217-2224, 2010.

DELGADO, F.J. et al. Formation of the aroma of a raw goat milk cheese during maturation analysed by SPME - GC - MS. Food Chemistry, v.129, p.1156-1163, 2011.

DIEZHANDINO, I.; FERNÁNDEZ, D. Rheological, textural, colour and sensory characteristics of a Spanish blue cheese (Valdeón cheese). LWT-Food Science and Technology, v.65, p.1118-1125, 2016.

HORT, J. et al. Changes in the perceived textural properties of cheddar cheese during maturation. Journal of Sensory Studies, v.12, n.1997, p.255-266, 1996.

LIM, J. Hedonic scaling : a review of methods and theory. Food Quality and Preference, v.22, n.8, p.733-747, 2011.

MITTERER-DALTOÉ, M. et al. Acceptance of breaded fish (Engraulis anchoita) in school meals in extreme southern Brazil. Acta Alimentaria, v.42, n.2, p.275-282, 2013a.

MITTERER-DALTOÉ, M.L. et al. Reasons underlying low fish consumption where availability is not an issue. a case study in Brazil, one of the world's largest fish producers. Journal of Sensory Studies, v.28, n.3, p.205-216, 2013b.

OLSEN, N.V. et al. Predicting consumers intention to consume ready-to-eat meals. The role of moral attitude. Appetite, v.55, n.3, p.534-539, 2010 .

ORDÓÑEZ, J.A. et al. Tecnologia de alimentos: alimentos de origem animal. [s.1.]: Artmed, 2005. p.279.

PRATI, G. et al. The prediction of intention to consume genetically modified food: Test of an integrated psychosocial model. Food Quality and Preference, v.25, n.2, p.163-170, 2012. 
QUEIROZ, M.I.; TREPTOW, R.O. Análise sensorial para avaliação da qualidade dos alimentos. Rio Grande: Furg, 2006. 268p.

SBAMPATO, C.G.et al. Queijo gorgonzola fabricado com leite pasteurizado por ejetor de vapor e HTST: parâmetros físico- químicos e sensoriais. Pesquisa Agropecuária Brasileira, v.35, n.1, p.191-200, 2000.

STEELE, J. et al. Perspectives on the contribution of lactic acid bacteria to cheese flavor development. Current opinion in biotechnology, v.24, n.2, p.135-141, 2013. 